\title{
LEGAL ASPECTS OF THE AGRICULTURAL LAND PROTECTION IN SLOVAKIA
}

\author{
PRÁVNE ASPEKTY \\ OCHRANY POLNOHOSPODÁRSKEJ PÔDY \\ NA SLOVENSKU
}

\author{
Lucia PALŠOVÁ - Ina MELIŠKOVÁ - Anna BANDLEROVÁ *
}

\section{Introduction}

In spite of large-scale legislative activity in Slovakia last period in all spheres of economy we could hardly find any section where more legislative changes were adopted than in the sphere of agriculture. Increasingly, the world is experiencing severe environmental, social and economic problems that are challenging current production systems and the sustainability of all human activities. Indeed, the resources on which these activities depend are significantly imbalanced, land resources, in particular. This has severe consequences for all economic and social activities.

Regarding the land market, the supply curve is growing in a short period and it has a vertical shape in the long term, because it cannot exceed the constraint level given by the nature ${ }^{(1)}$.

Although, agricultural land is seen as an important natural resource and the wealth of each country ${ }^{(2)}$.

Throughout the world land is under intense pressure. In many countries, the human population is expanding fast and the demands on natural resources are increasing. Under this pressure, significant land degradation is taking place and

(1) LAZÍKOVÁ, J - TAKÁČ, I. - BUDAY, Š. 2012. Economic and legal aspects of the agricultural land market. In: Agricultural economics, vol. 4, no. 58, pp. 172-179.

(2) LAZÍKOVÁ, J. et al. 2015. Agricultural land market in Slovakia economic and legal impacts of the Law no. 140/2014 Coll. on the land acquisition. In: Agricultural Economics, Praha, vol. 61, no. 8, pp. 367-376. ISSN 0139-570X.

\section{Abstract (EN)}

Protection of the functions and surface area of agricultural land should be the interest of every society and is an expression of the maturity of the country. The paper analyses historical development of the legal regulation on the protection of agricultural land in Slovakia since the establishment of Czechoslovakia i.e. from 1918 to the present, i.e. until 2017.

\section{Keywords (EN)}

agricultural land, protection of agricultural land, legislative development land productivity is reducing. The situation in many countries is not sustainable, even though strenuous efforts have been made to halt degradation ${ }^{(3)}$. Land is a crucial, but limited and in the conditions of human life, a non-renewable natural resource. Land protection must be integral part of long-term state policy objectives. When using and protecting the land, the concept of sustainability must be consistent with the interest in a non-conflictual future and in accordance with the human right to safe nutrition and other benefits of the land use ${ }^{(4)}$. Agricultural land is protected by each owner or user. In addition, there is the interest of the owner to let his land plots to the best users who ensure not only profit for themselves but also the land cultivation and protection $^{(5)}$. In Slovakia, most agricultural land is rented and cultivated by the tenants, not by the owner. The Slovak lawmaker adopts a special legal regulation with the aim to stabilise the land rent relations, to protect the interests of the agricultural

(3) INTOSAI WGEA. 2013. Land Use and Land Management Practices in Environmental Perspective. Morocco: Supreme Audit Institutions 79 s. ISBN 978-9949-9061-9-2.

(4) ILAVSKÁ, B. - BEZÁK, P. 2015. Nový legislativny rámec ochrany pôdy v SR. Zborník referátov a diskusných príspevkov. Lužianky Národné polnohospodárske a potravinárske centrum, 49-56 s. ISBN 978-80-89418-43-5.

(5) LAZÍKOVÁ, J. 2014. Prednostné právo uživatelov pôdy na uzatvorenie nájomnej zmluvy. In Agrárne právo EÚ, vol. 3, no. 1, pp. 19-23. ISSN 1339-9276.

\section{Abstrakt (SK)}

Ochrana funkcií a výmery pol'nohospodárskej pôdy by mala byt' záujmom každej spoločnosti a je prejavom vyspelosti daného štátu. Príspevok analyzuje historický vývoj právnej úpravy ochrany polnohospodárskej pôdy na Slovensku od obdobia vzniku Československa, t.j. od roku 1918 až po súčasnost', t.j. do roku 2017. Poskytuje systematický prehlad právnej úpravy na úseku ochrany polnohospodárskej pôdy $v$ troch časových obdobiach, t.j. v období rokov 1918-1958, 1959-2003 a 2004-2017.

\section{KPưčové slová (SK)}

polnohospodárska pôda, ochrana polnohospodárskej pôdy, legislatívny vývoj

\footnotetext{
* Slovak University of Agriculture in Nitra
} 
land tenants and to protect the soil as the natural resource ${ }^{(6)}$. Based on existing statistics, we can say that the country's development often depends on the quality of the land, while countries with better land quality being usually better off. Paradoxically, developed countries with a good land quality suffer the most from degrading and declining of land. Approximately 275 hectares of land a day is withdrawn in the European Union $^{(7)}$. In Slovakia, it is 7-8 hectares ${ }^{(8)}$.

There are various approaches to land protection. They differ only in the efforts to point out that something is being done in this area. However, the truth is that we have moved only a little closer to the ideal state, in which the threats to soil are stopped or at least reduced to a professionally and socially acceptable level.

The European Soil Thematic Strategy defines the main processes of soil degradation - the reduction of its quality, partial or complete loss of one of its functions, which often influence each another. These are erosion, soil organic matter loss, soil contamination, salinization, soil biodiversity loss, soil compaction, landslides and floods and usage for non-biological purposes. The most common causes of soil degradation are natural factors and human activity - anthropogenic soil degradation where the process is caused by human activity that reduces the present or future capacity of the soil to enable human life.

These are large land withdrawals, usually meaning eventual destruction of soil. It is therefore necessary to protect the land, and an important part of its protection is to raise people's awareness of its importance and protection ${ }^{(9)}$. This is also confirmed by the Council of Europe, which adopted the European Soil Charter, under which the land is an easily destroyable and limited natural resource, and it is essential to ensure its systematic research and education on land protection at all levels ${ }^{(10)}$.

The Slovak legal order has paid increased attention to the protection of the agricultural land for decades, which results from the fact that the Slovak Republic has relatively little land, on average not of the highest quality, considering the population and the needs for its nutrition ${ }^{(11)}$. The total land area of the land fund in the SR as of January 1, 2016 is 4, 903, 459 ha of land, of which the agricultural land occupies

(6) TAKÁČ, I. - LAZÍKOVÁ, J. 2013. Právna úprava nájomných zmlúv na trhu s prenajímaním pôdy na Slovensku. In Agrárne právo EÚ, vol. 2, no. 1, pp. 32-36. ISSN 1338-6891.

(7) PROKOP, G. et al. 2011. Report on best practices for limiting soil sealing and mitigating its effects. Technical Report - 2011 - 050. European Comunities, 127 s. ISBN 978-92-79-20669-6.

(8) BIELEK, P. 2014. Kompendium praktického pôdoznalectva. Nitra: Slovenská polnohospodárska univerzita v Nitre. 244 s. ISBN 978-80-552-1155-8.

(9) VEREŠPEJOVÁ, A. 2009. Čistá pôda - bude ešte? [online], [accessed: 2016-11-21]. Available at: 〈http://www . agroserver . sk/news/cista-poda-bude-este>.

(10) RADA EURÓPY, 1972. Európska charta o pôde, [online], [accessed: 2016-11-22]. Available at: <http://eur-lex. europa. eu/homepage. html >

(11) ŠTEFANOVIČ, M. 2009. Právna úprava ochrany pôdy v Slovenskej republike. Česká společnost pro právo životního prostředí. [online], [accessed: 2016-11-21]. Available at: <www.cspzp.com/ dokumenty/konference01/stefanovic. doc $>$.
2, 389, 616 ha $^{(12)}$. During one calendar year, with regard to changes in the permanent nature and the specification of the area, we recorded a loss of 7,425 ha of agricultural land ${ }^{(13)}$. The area of agricultural land is constantly decreasing. In the last ten years 41,067 hectares of agricultural land have been lost in Slovakia ${ }^{(14)}$.

The paper is mapping the development of the legislation on the protection of agricultural land in Slovakia in three time periods, in the years 1918-1958, 1959-2003 and 2004-2017.

\section{Material and methods}

The aim of the article is to analyse the historical development of the regulation of agricultural land protection in Slovakia between 1918 and 2017.

The legislative development in agricultural land protection was monitored for three time periods, namely the period 1918-1959, the period 1959-2003, and the period 20042017.

The method of analysis, comparison, deduction and synthesis was used to achieve the aim. The source of information was the legislation, explanatory reports to the legislation, statistical yearbooks as well as opinions of experts in the field.

\section{Development of legislation on the protection of agricultural land from the establishment of Czechoslovakia in 1918 until 1958}

The development of agricultural land protection legislation correlates with the socio-economic determinants of a particular historical period. In the period 1918-1958, there was no legislation regulating the comprehensive protection of the biological properties of agricultural land, although the rules governing legal relations with agricultural land indirectly affected agricultural land management.

Since 1918, i.e. since the establishment of Czechoslovakia, it was necessary to consolidate the ownership and use relations of citizens of Czechoslovakia. In the framework, the leg-

(12) Štatistická ročenka o pôdnom fonde v SR podla údajov katastra nehnutelností k 1. januáru 2016. Bratislava : Úrad geodézie, kartografie a katastra Slovenskej republiky, 128 s. ISBN 978-8089831-02-9.

(13) Ibid.

(14) Štatistická ročenka o pôdnom fonde V SR podla údajov katastra nehnutelností k 1. januáru 2016. Bratislava : Úrad geodézie, kartografie a katastra Slovenskej republiky, $128 \mathrm{~s}$. ISBN 978-80-89831-02-9; Štatistická ročenka o pôdnom fonde $\mathrm{v}$ SR podla údajov katastra nehnutelností $\mathrm{k}$ l. januáru 2007. Bratislava: Úrad geodézie, kartografie a katastra Slovenskej republiky, 128 s. ISBN 978-80-22409-90-2. 
islation $^{(15)}$ of the so-called land reform the idea of land ownership was gradually created, on the basis of which a part of the land ownership of the estates was de jure confiscated, while the maximum size of the estates could not exceed 150 ha of agricultural land (fields, meadows, gardens, vineyards and hop fields). During this period, a total of $1,312,721$ hectares of agricultural land ${ }^{(16)}$ in Slovakia was confiscated and subsequently allocated to new owners designated by the State Land Office. The aim of the land reform was, among other things, to provide a livelihood for the population, and therefore the legal regulation of the management of agricultural land emphasized the land as a factor of production rather than environmental aspects of land protection. This trend continued until the mid-1980s.

The legal regulation of relations to agricultural land in Slovakia was influenced, in the period of World War II (19391945), by signing of the first Vienna Arbitration (1938), as a result of which Slovakia lost its agricultural land, which produced up to $80 \%$ of all foodstuffs ${ }^{(17)}$. The land reform (Act No. 46/1940 Coll., on Land Reform) continued on the other agricultural land in Slovakia, which resulted in the withdrawal and parcelling of agricultural land of the defined groups of the population, which was subsequently allocated to farmers of Slovak origin.

The land reforms regarding land ownership from previous periods were in force, with the particular legislation amending:

- prohibition of tillage of agricultural land (Act No. 139/1947 Coll. on division of estates with agricultural holdings and on prevention of the tillage of agricultural land);

- agricultural and forest land disposition (Act No. 65/1951 Coll. on real estate transfers and renting of agricultural and forest land).

In the period after World War II, it was necessary to ensure the use and expansion of agricultural land to a sufficient extent. The adopted Act No. 55/1947 Coll. on the assistance

(15) Právne predpisy regulujúce pozemkové vlastníctvo v rokoch 1918-1939:

- zákon č. 32/1918 Sb. z. a n. o obstavení velkostatkov;

- zákon č. 67/1918 Sb. z. a n. o mimoriadnych opatreniach na Slovensku;

- zákon č. 215/1919 Zb. z. a n. o zabraní vel'kého pozemkového vlastníctva, tzv. „záborový zákon“;

- zákon č. 318/1918 Zb. z. a n. o zabezpečení pôdy drobným nájomníkom;

- zákon č. 330/1919 Zb. z. a n. o pozemkovom úrade;

- zákon č. 81/1920 Zb. z. a n. o prídele zabranej pôdy

(prídelový zákon);

- zákon č. 329/1920 Zb. z. a n. o prevzatí a náhrade za zabraný pozemkový majetok.

(16) SLEZÁK, L. 1994. Pozemková reforma v Československu 1919 1935. In: Československá pozemková reforma 1919 - 1935 a její mezinárodní souvislosti. Uherské Hradište, p 3.

(17) SABOL M. 2010. „Až na dno blahobytu (Hojnost alebo chudoba slovenských rodin $v$ Slovenskej republike 1939 - 1945)", In: SOKOLOVIČ P. Život v Slovenskej republike. Slovenská republika 1939-1945 očami mladých historikov IX, Bratislava: Ústav pamäti národa, ISBN 978-80-89335-37-4. of farmers in the implementation of the agricultural production plan stated that in the interest of nutrition of the population, all agricultural land must be farmed in accordance with the agricultural production plan. Pursuant to Paragraph 1 of this Act, the State was required to ensure that every agricultural land was farmed and conversely, in the case where the farmer was unable to ensure the land management, the competent authorities ensured it. Removal of agricultural land for another purpose was subject to the approval of the District National Committee. This Act was amended by Act No. 132/1948 Coll. and by Act No. 244/1949 Coll.

According to Paragraph 41 section 2 of Act No. 241/1948 Coll., on the first five-year economic development plan of the Czechoslovak Republic (act on the five-year plan), the Government adopted Regulation No. 55/1951 Coll. on the expansion of arable land area and the safeguarding of land for agricultural production. The purpose of this government regulation was to ensure proper management of agricultural land, in particular arable land and its planned expansion, mainly from agricultural land. The government regulation, following previous legislation, has protected the size of agricultural land in two ways:

1. conversion of individual types of agricultural land was subject to the consent of the District National Committee (§3);

2. change of agricultural land to non-agricultural land out of the building area of the municipality (\$4) was in principle impossible; At the same time, it is stipulated that land-use planning should regard maintaining of arable land. If the farmer changed the purpose of the agricultural land without consent, he/she was obliged to return the land to the original purpose.

In the period 1918-1958 a land reform took place in Slovakia, respectively Czechoslovakia. Because of this reform agricultural land was allocated to state-appointed persons. In terms of protection of agricultural land, the legislation mainly aimed at expanding the size of agricultural land, in particular arable land, and protecting it from non-agricultural purposes.

\section{Development of legislation on the protection of agricultural land in 1959-2003}

In the 1950s, the reconstruction of the countryside was realized through socialization, and a new period of organizational consolidation of socialist agricultural enterprises was underway, as well as the stabilization of the land base of cooperatives and the period of the overall transition to the scientific and technical base of socialist mass production. By adopting Act No. 48/1959 Coll. on the protection of agricultural land, agricultural land was defined as an irreplaceable basic production means of agricultural production. Paragraph 2 of the Act for the first time defines the agricultural land fund and its part, which is the land farmed and the land which has been 
and should continue to be farmed but the farming has been temporarily interrupted; at the same time the land which is economically justifiable to farm, in particular the land which, prior to the effectiveness of this law, has been taken away from agricultural production, and the land which does not directly serve agricultural production but is indispensable for agricultural production may be declared a part of the agricultural land fund. As a result of the previous legislation, the new act regulated the continued expansion of agricultural land and the conversion of agricultural land into arable land ( $\$ 2-\S 4$ of the Act). The Act regulated for the first time, in addition to the quantitative and qualitative characteristics of agricultural land, during the process of the management of land and its modifications, in order not to reduce or worsen the agricultural land, but to increase the fertility of the land ( $\$ 7$ of the cited act). The protection of agricultural land was in addition to the general ban on the removal of agricultural land for non-agricultural purposes, specifically extended to the protection of the agricultural land fund in the operation of industrial enterprises, construction of roads and water works, geological and hydrological survey and construction of overhead and underground lines. Paragraph 8 section 3 of the Act stated that, when removing agricultural land, it must be ensured that agricultural land of inferior quality is used first and that as little area of agricultural land as possible is removed. The District National Committee was a competent authority for the removal of agricultural land, in more complicated cases it was the Regional National Committee.

In order to reduce the removal of agricultural land and make the protection of agricultural land more effective, Act No. 53/1966 Coll. on the Protection of Agricultural Land Fund was adopted, repealing Act No. 48/1959 Coll. In § 1 the Act redefines the agricultural land fund, which is used for agricultural land (arable land, hop fields, vineyards, gardens, fruit orchards, meadows, pastures) and land which should have been farmed but the farming has been temporarily interrupted. At the same time, it stipulated that the land fund also includes the land which does not directly serve agricultural production, but it is indispensable to it, such as field roads, land with equipment important for irrigation, water reservoirs and ponds needed for agricultural production, dams to protect against wetting or flooding, protective terraces against erosion, etc.

The Act clarifies the previous legal regulation as regards the extension of the agricultural land fund to new land in municipalities to be declared as a part of it, the use of the fund for agricultural production and changes of the cultures within the fund.

The principles of the protection of agricultural land (Part III of the Act), as in the previous legislation, were directed only to the protection of agricultural land and the preservation of the purpose of its utilization. The principles of protection of the agricultural land fund were to be complied with if, in cases of necessity, justified by the social interest, the components of the agricultural land fund were removed or if the use of the land fund became more difficult. It was also necessary to comply with the obligations relating to the protection of the agricultural land fund in carrying out various activities such as land-use planning, mining and industrial activities and processing of preparatory documentation of buildings.

Pursuant to that legislation, withdrawal of the components of the agricultural land fund of agricultural production was possible only on the basis of the prior consent of the competent authority, taking into account the socio-economic interests, the political and economic justification of the withdrawal, but also the estimation of losses in agricultural production.

For the first time, contributions were incorporated into the law as an economic tool for the protection of land and the preservation of the culture of agricultural land. Withdrawal contributions were paid not only to the state budget, but also to the funds of individual cooperatives. The contributions, the amount of which was specified by the District National Committee, were paid by the entity, which took the land away from agricultural production. Payments were made for both permanent and temporary withdrawals of agricultural land. In case of permanent withdrawals of agricultural land from agricultural production, the contributions were set when the value of the annual gross production of 1 ha in the normal way of farming exceeded 1500 CSK (Czechoslovak Crowns) in case of meadows and pastures 750 CSK. The basic rate of contributions was 50 times, in case of meadows and pastures, 100 times the annual gross production of crop production reached on the land under the normal way of farming. In case of temporary withdrawals, the contributions were paid each year of the withdrawal in the amount of gross production of crop production on the land taken. In the cases determined by law, it was possible to reduce the amount of contributions as well as to exempt from the payment of the contributions. To implement certain provisions of the Act, a Decree of the Ministry of Agriculture and Forestry No. 97/1966 Coll., was introduced, implementing certain provisions of the Act on the Protection of Agricultural Land Fund.

Contributions were one of the main revenues of the State Land Regeneration Fund, which was established by the Ministry of Agriculture and Food of the Slovak Socialist Republic by Act No. 179/1969 Coll. The State Land Regeneration Fund was obliged to use the funds obtained from the contributions for the development of agricultural production, especially for the re-cultivation and reclamation of agricultural land.

In 1976, Act No. 53/1966 Coll. was amended by Act No. 75/1976 Coll. amending Act No. 53/1966 Coll. on the Protection of Agricultural Land Fund. The reason for adopting the amendment was to introduce stricter and more rigorous protection of agricultural land. The amendment of the Act, in $\S 1$ section 1 , for the first time, defines agricultural land as the basic natural wealth of our country, irreplaceable means of production enabling self-sufficiency in the production of basic foods and as one of the main components of the environment. Protection of the agricultural land, its enhancement, exploitation and expansion were among the leading tasks of the then socialist society. The amendment also tightened the economic protection instruments by introducing objectively decisive considerations for determining the amount of the contributions. It also determined the payment of fines for breaching the obligations imposed by law and included a compensation for economic harm caused to 
a socialist agricultural organization by removing the land in a larger scale or by impairing or restricting its management.

Withdrawals of arable land in the 1st and 2nd class were forbidden by the amendment. It considered the arable land with investment measures taken to increase the intensity of agricultural production, the agricultural land with hop fields, vineyards, intensively managed orchards and vegetable areas and the agricultural land used for the purpose of constructing recreational chalets and objects. Withdrawals of a part of the agricultural land fund from agricultural production was a subject to prior approval of the competent authority, which was the authority for the protection of the agricultural land fund. The fund assessed the economic impact of the withdrawal, and in case of a major interference with the management of the socialist agricultural organization, the fund also estimated the economic damage. The amendment kept the option of removing the agricultural land permanently or temporarily, but a maximum period in case of a temporary withdrawal was twelve years. The entity that requested a permanent or temporary land withdrawal from agricultural production was obliged to pay a specific amount of contributions to the Land Fund for the land improvement. In case of a permanent withdrawal, the contributions were paid on a one-off basis and in case of a temporary withdrawal these were paid on an annual basis until the re-cultivation ended, after which the land was returned to the agricultural production. Basic rates of the contributions were specified by the Czechoslovak Government Order No. 103/1976 Coll. on rates of contributions for agricultural land of agricultural production. The rates of the contributions were annexed to the Order. Basic rates were set according to the natural habitat and the quality class of the land in thousands of CSK per hectare, basic rates for meadows and pastures were decreased by $30-80 \%$. In case of a temporary withdrawal, the contributions were paid each year at a rate of between $0.5-2 \%$ of the basic rate per hectare per year according to the natural habitat and the quality class. The Order kept the possibility of lowering the contributions for an organization that fertilized or reclaimed agricultural land and other types of land. The Order also specified statutory conditions of the exemptions from contributions payment. Fines could be imposed for the breach of the obligations laid down by the law on land protection. The fines could be imposed by the bodies of the protection of the agricultural land fund up to 500,000 CSK.

Political-social changes, and the new legal environment in the Slovak Republic after 1990, were the reason for the adoption of the new Act No. 307/1992 Coll. on the Protection of Agricultural Land Fund. The Act, which has been amended several times, has defined the agricultural land fund in its opening clause as an indispensable component of the environment and an irreplaceable natural resource, and has imposed an obligation to protect its natural functions and to avoid acts that would lead to its deterioration. Unlike the previous legislation, the Act made an owner, a tenant, or a land manager explicitly responsible for the agricultural land protection.

The Act defined the way of using the agricultural land fund following the definition of the land types in the cadas- tre. It was a way of exploitation that respected the natural conditions in the given area, guaranteed the preservation or restoration of the natural features of agricultural land, the functional connections of natural processes. At the same time the Act did not threaten the ecological stability of the territory. The Act regulated basic obligations to preserve the natural qualities of the agricultural land fund; it laid down the measures for elimination of bad conditions and ordered the establishment of a special system of management due to threats to the agricultural land fund. A withdrawal of agricultural land was only possible after the consent of the body for the protection of agricultural land, in the area where the agricultural land or the largest part of it was withdrawn. That legislation also laid down the obligation to pay contributions for the withdrawal of agricultural land from the agricultural land fund.

The entity that requested the withdrawal of agricultural land had to pay the contribution to the State Fund for the Protection and Improvement of the Agricultural Land Fund. The State Fund for Protection and Improvement of Agricultural Land Fund was established by law and its purpose was to provide means for preservation and restoration of the natural qualities of agricultural land as well as the overall increase of the agricultural land fund. Fund resources were constituted by contributions and fines stipulated by law, a part of the revenues of the Slovak Land Fund, subsidies from the state budget and other sources stipulated by the law. The Fund was managed by the Ministry of Agriculture and Food of the Slovak Republic. Statutory rates of contributions were laid down in Government Order No. 19/1993 Coll. on the basic rates of contributions for the withdrawal of agricultural land from the agricultural land fund. The Regulation also laid down the method of payment and maturity of the contributions for a temporary and a permanent withdrawal of agricultural land, the area of agricultural plots from which the contributions were calculated and the conditions and extent of the increase or decrease of the basic rates and the exemption from contributions. Contributions for permanent but also for temporary withdrawals were paid on a one-off basis. The rate of the contributions, which was annexed to the Regulation, was based on the basic rates of both permanent and temporary withdrawal contributions, according to group 1-9 and the CSEU code in CSK per hectare. Fines for breaching statutory obligations in the field of land protection were set. The fines could still be imposed by the bodies of the protection of the agricultural land fund up to 1,000,000 CSK. The Ministry of Agriculture and Food of the Slovak Republic was nominated as a body of protection of the agricultural land fund. District offices and Regional offices were nominated to be central state administration bodies in the matters of protection of the agricultural land fund.

The impetus for a new approach to land protection was the resolution of the Slovak Government no. 1141 of December 6, 2001 on the proposal for the principles of the Slovak State's Land Policy, approved on December 6, 2001 under the title "Principles of the State Policies of the Slovak Republic". The resolution defined the soil as the top layer of the weathered surface of the earth's crust containing water, air and living organisms. It defined the different soil 
functions, namely organic (biomass production, filtration, neutralization and conversion of substances in nature and maintenance of the ecological and genetic potential of living organisms) and functions related to human activities (part of the spatial basis for socio-economic activities, source of raw materials and natural heritage of the country).

Compared to the previous legal regulation, the resolution has a greater focus on organic function of soil. Stability of the soil organic matter also significantly depends on the natural resistance of the organic matter to decomposition, which crucially depends on its internal structure, which was quite fittingly presented by Baldock and Skjemstad ${ }^{(18)}$.

The resolution, emphasized the correct use of land, respecting the principles and criteria of sustainable development, it also dealt with the protection of the quality and quantity of land. The resolution underlined that land protection is carried out in the context of the protection of environmental compartments with the aim to achieve the stabilization of the area and the area of the best quality land and to prevent its unreasonable withdrawal.

The State Administration of Land Protection was established. It was executed by the Ministry of Agriculture of the Slovak Republic and bodies of local state administration. The above-mentioned resolution highlighted the role of monitoring and a comprehensive information system on the status, characteristics and the development of land quality. This permanent and state-supported knowledge on land-use was also made to contribute to the development and updating of international land documents. The resolution also focused on international integration, in which it is crucial to implement the principles applied in the European Union and other international principles and rules serving to protection and proper usage land. This resolution declared a state land policy that clearly defined the principles and priorities of the state towards the land as a basic and non-renewable natural resource and national wealth and the heritage of future generations. By adopting the Principles of State Land Policy of the Slovak Republic, the Government of the Slovak Republic has fulfilled the objective of implementing land protection initiatives coming from the world, especially from the European Union.

\section{Development of the land protection legislation in $2004-2017$}

The adoption of Act No. 220/2004 Coll. on the protection and use of agricultural land and on the amendment of Act No. 245/2003 Coll. on Integrated Prevention and Control of Environmental Pollution and on the Amendment and Supplementation of Certain Acts was a response to the Government Resolution no. 1141 of 2001. The cited act was amend-

(18) BALDOCK, J. A. - SKJEMSTAD, J. O. 1999. Soil organic carbon/ soil organic matter. In: Soil Analysis: an Interpretation Manual (Peverill, K.I. - Sparov, L.A. - Reuter, D.J.), s. 159 - 170, CSIRO Publishing: Collingwood. ed eight times ${ }^{(19)}$. The concept of agricultural land fund was replaced by the term agricultural land. The act emphasizes the protection of the environmental functions of agricultural land, ensuring its sustainable management and exploitation, as declared in the Principles of State Land Policy. Basic legal concepts were specified, defining agricultural land as production potential land recorded in the real estate cadastre as arable land, hop fields, vineyards, orchards, gardens and permanent grassland; the law also defined the concept of the Credit Soil-Ecological Unit (hereinafter CSEU) as a classification and identification data expressing the quality and value of the production and ecological potential of the agricultural land at the site. The act stipulated that each owner or user of agricultural land had to protect agricultural land from degradation, erosion, compaction and from hazardous substances. The principles of sustainable land use, management and conservation were defined and changes in land types were legally specified. In accordance with this legislation, the Agricultural Land Protection Authority gives consent, at the request of the owner or user, with a change of the type of agricultural land, a change of the non-agricultural land to agricultural land or afforestation of agricultural land.

At the same time, the act defined the principles of the protection of agricultural land even when the land was used for non-agricultural purposes. Agricultural land could be used for construction purposes and other non-agricultural purposes only in the necessary cases and to a reasonable extent, in accordance with the cited act.

It is possible to withdraw agricultural land permanently or temporarily in accordance with the act. The act allows the use of agricultural land for non-agricultural purposes for a period of up to one year, including the restoration of the land to the original condition. By a permanent withdrawal of agricultural land, the act understands a permanent change in the way of using agricultural land with a permanent change of the land type in the cadastre. A temporary withdrawal is understood as a temporary change in the use of agricultural land for a maximum of ten years, which will be restored with the reclamation measures. The Agricultural Land Protection Authority, according to the original act, was the Ministry of Agriculture (central body for the protection of agricultural land), the Regional Land Office (coordinator of the cooperation with the Soil Service) and the District Land Office (it mainly decided about the agricultural land withdraws, imposed fines, and cooperated with the Soil Service). From 2013 the Agricultural Land Protection Authority are: the Ministry of Agriculture and Rural Development, the District Land Office at the County and District Land Office. These bodies performed expert supervision in cooperation with the newly established Soil Service, which was obliged by the law to conduct surveys and monitor agricultural land, to keep a database of agricultural land and to draft measures and expert opinions according to the law. Fines could be imposed for violations of agricultural land protection. Seriousness, manner and duration of the unlawful act and the extent and degree of the damage or the damage suffered were

(19) Zákony č. 359/2007 Z. z., 540/2008 Z. z., 219/2008 Z. z., 396/2009 Z. z., 39/2013 Z. z., 57/2013 Z. z., 34/2014 Z. z., 254/2015 Z. z. 
considered when determining the amount of the fine. The fine was imposed by the authority for the protection of agricultural land and the profit from the fines represented the income of the state budget. Each of the legal regulations that used the institute of contributions for the land withdrawal at the same time introduced numerous exceptions to the obligation to pay contributions. Exceptions related to about 70\% of all agricultural land withdrawals, making the institute of contributions in the legislator's opinion non-systemic and undemocratic, which led to the abolition of the contributions at a given time. The law abolished the contributions, but on the other hand, it tightened the legislation on the protection of agricultural land. Categories and limit values related to erosion, compaction, soil organic matter quality, liming of agricultural land, limit values of risk substances in agricultural land, which were understood as the values of the maximum permissible contents of the hazardous substances and the degree of contamination were established. Only the fines were allowed as a single economic tool for the protection of agricultural land against its withdrawal for non-agricultural purposes. By this step the legislator expected a positive impact on landowners and users of agricultural land. The reduction of the state budget for the income from payments for the withdrawal of agricultural land should have been partly compensated by an increase in contributions and taxes from business activities on withdrawn land.

It turned out that the abolition of the contributions for the withdrawal of agricultural land for non-agricultural purposes did not produce the effect the legislature expected at the time of the adoption of Act 220/2004 Coll., when it abolished the contributions and thus, five years after, the amendment to Act No. 220/2004 Coll., namely Act No. 219/2008 Coll. with the effect from January 1, 2009 was adopted. This amendment re-introduced the contributions but only for the withdrawals of agricultural land classified under the CSEU code into groups 1 to 4 . The conditions for the withdrawal of agricultural land for constructions and other non-agricultural purposes were tightened through the institute of the contributions for the withdrawal of agricultural land as a systemic economic tool for the protection of the highest quality agricultural land. Payments of the contributions had a positive effect to the increase of the state budget revenues and thus the financing of the activities of the Ministry of Agriculture of the Slovak Republic in the form of a balanced balance between the revenues and expenditures of the budget chapter of the Ministry of Agriculture of the Slovak Republic in the respective budget year. The legislator, by imposing the withdrawal contributions, planned to achieve three socio-economic aims: protection and stabilization of the best agricultural land in Slovakia, guiding and eventually forcing construction investors to orient themselves to Slovakia's locations outside the Bratislava and Trnava regions on lower quality land (CSEU in the 5th to Group 9) and less important locations for primary agricultural production where the level of contributions will be lower, and also to limit their soil requirements to the necessary extent of a withdrawal, and finally to secure funds for the implementation of certain provisions of the Act, such as activities concerning the organization of agricultural land registration in the cadastre with the real state in the field and the creation of an information system on soils. Payments for the permanent or temporary withdrawal of agricultural land shall be payable by those who have proposed its use for non-agricultural purposes. In case of a permanent withdrawal, there was a permanent change in the use of agricultural land with a permanent change of land type in the cadastre, and in case of a temporary withdrawal, it is a temporary change in the use of agricultural land for a maximum of ten years, which should be restored with the reclamation measures. The obligation to pay a fee also applies to those who have withdrawn the agricultural land without a decision of the Agricultural Land Protection Authority. If the contributions were not paid in time, it was the duty to pay the penalty of $0.5 \%$ of the unpaid amount for each commenced day of the delay. Both contributions and penalties constitute the income of the state budget. The amount of the contributions was not specified by the law, but in this respect the Order of the Government of the Slovak Republic no. 376/2008 Coll. was adopted, specifying the amount of the contributions and the method of payment of the contributions for the withdrawal of agricultural land, establishing the amount of the contributions and the method of payment. The amendment set out new issues concerning the exemption from the agricultural land withdrawal contributions, but only if there was no suitable land listed under the CSEU code in the $6^{\text {th }}$ to $9^{\text {th }}$ group in the cadastral area of the municipality.

Another major amendment to Act No. 220/2004 Coll. was Act No. 57/2013 Coll. amending Act No. 220/2004 Coll. on the protection and use of agricultural land and on the amendment of Act No. 245/2003 Coll. on the integrated prevention and control of environmental pollution and on the amendment and supplementation of certain laws as amended, and on amendments to certain laws with effect from April 1, 2013. The reason for adopting the amendment was, among other things, to adjust the scope and extent of the institute of contributions for the withdrawal of the highest quality agricultural land in the relevant cadastral territory. The amendment was based on the need to protect the institute of contributions of the best agricultural land in the cadastral territory proportionally throughout the territory of the Slovak Republic, by individual protection of the specifically listed CSEU codes in the individual cadastral territories. The solution was an updated table of qualitative groups (CSEU codes) with the assignment of the contributions for the withdrawal of agricultural land by a quality group in $€ / \mathrm{m}^{2}$ for each cadastral territory within the territory of the SR. Therefore, the contributions had to be paid as it is in the current legislation for every agricultural land in Slovakia for all credit groups. A specifically defined scope of exemptions from the payment of the contributions was abolished by the amendment as it represented about $70 \%$ of all agricultural land withdrawals as described above. The amendment to the scope of exemptions from the payment of contributions was laid down by Government Regulation No. 58/2013 Coll. on contributions for the removal and the unauthorized withdrawal of agricultural land. In addition to exempting from the contributions, the government decree also established the basic rate of contribution for the agricultural land removal and the unauthorized land withdrawal, the list 
of the best quality agricultural land in the cadastral area under the CSEU codes, the amount of contributions, the method of payment of contributions and the maturity of contributions. One of the exceptions to the payment of the contributions for the agricultural land withdrawal was the situation when a building certificate was issued as a significant investment of at least 1 billion EUR of investment costs and at least 2000 new jobs were created. The European Commission believed the existence and application of this exemption from the payment of contributions is an unlawful State aid and distorts competition. The legislator accepted the reservations of the European Commission and adopted an amendment to Government Regulation No. 58/2013 Coll., namely Government Order No. 363/2016 Coll. by which the contested provision was dismissed.

\section{Conclusion}

The development of the legislation was followed over three periods of time. During the years 1918-1959, when the legislator focused mainly on the expansion of agricultural land and the prohibition of its fragmentation. The period 19592003, when not only the size of agricultural land and the purpose of its use was protected, but the soil functions, whether ecological or functions associated with human activities, were gradually protected. The emphasis on the proper use of land that respects the principles and criteria of sustainable development was put. In addition, since 1966, contributions for the withdrawal of agricultural land for non-agricultural purposes have also been used as an economic tool of the protection and preservation of agricultural land. The period 2004-2017, when the legislator established an obligation for each owner or user of agricultural land to protect agricultural land from degradation, erosion, compaction and hazardous substances and defined the principles of sustainable land use, management and conservation. The beginning of this period is characterized by the fact that, over a period of five years, from 2004 to 2008, the obligation to pay contributions for the withdrawal of agricultural land for non-agricultural purposes was abolished. The contributions have been reintroduced in 2009 and are being used since then.

\section{Acknowledgement}

Results of the paper are based on the research tasks of the Jean Monnet Networks project no. 564651-EPP-1-2015-1-SKEPPJMO-NETWORK "Sustainable Land Management Network" and project "International University Cooperation on Land Protection in European-Asiatic Countries" No: 561841EPP-1-2015-1- IT-EPPKA2-CBHE-JP.

These projects have been funded with the support of the European Commission. This publication only reflects the views of the author, and the Commission cannot be held responsible for any use which may be made of the information contained therein.

\section{References}

1. BIELEK, P. 2014. Kompendium praktického pôdoznalectva. Nitra : Slovenská polnohospodárska univerzita v Nitre. 244 s. ISBN 978-80552-1155-8.
2. ILAVSKÁ, B. - BEZÁK, P. 2015. Nový legislatívny rámec ochrany pôdy v SR. Zborník referátov a diskusných príspevkov. Lužianky: Národné polnohospodárske a potravinárske centrum, 49-56 s. ISBN 978-8089418-43-5

3. INTOSAI WGEA. 2013. Land Use and Land Management Practices in Environmental Perspective. Morocco : Supreme Audit Institutions 79 s. ISBN 978-9949-9061-9-2.

4. LAZÍKOVÁ, J. 2014. Prednostné právo užívatelov pôdy na uzatvorenie nájomnej zmluvy. In Agrárne právo EÚ, vol. 3, no. 1, pp. 19-23. ISSN 1339-9276.

5. LAZÍKOVÁ, J - TAKÁČ, I. - BUDAY, Š. 2012. Economic and legal aspects of the agricultural land market. In: Agricultural economics, vol. 4 , no. 58 , pp. $172-179$.

6. LAZÍKOVÁ, J., TAKÁČ, I., SCHWARCZ, P., BANDLEROVÁ, A. 2015. Agricultural land market in Slovakia - economic and legal impacts of the Law no. 140/2014 Coll. on the land acquisition. In: Agricultural Economics, Praha, vol. 61, no. 8, pp. 367-376. ISSN 0139-570X.

7. PROKOP, G. et al. 2011. Report on best practices for limiting soil sealing and mitigating its effects. Technical Report - 2011 - 050. European Comunities, 127 s. ISBN 978-92-79-20669-6.

8. RADA EURÓPY, 1972. Európska charta o pôde, [online], [accessed: 2016-11-22]. Available at: <http://eur-lex.europa.eu/homepage. html>.

9. SABOL, M. 2010. „Až na dno blahobytu (Hojnosṫ alebo chudoba slovenských rodín v Slovenskej republike 1939 - 1945)", In SOKOLOVIČ P. Život v Slovenskej republike. Slovenská republika 1939-1945 očami mladých historikov IX, Bratislava: Ústav pamäti národa, ISBN 978 80-89335-37-4.

10. SLEZÁK, L. 1994. Pozemková reforma v Československu 1919 - 1935. In Československá pozemková reforma 1919 - 1935 a její mezinárodní souvislosti. Uherské Hradište, P 3.

11. Štatistická ročenka o pôdnom fonde v SR podla údajov katastra nehnutelností k 1. januáru 2007. Bratislava : Úrad geodézie, kartografie a katastra Slovenskej republiky, 128 s. ISBN 978-80-2240990-2.

12. Štatistická ročenka o pôdnom fonde v SR podla údajov katastra nehnutelností k 1. januáru 2016. Bratislava : Úrad geodézie, kartografie a katastra Slovenskej republiky, 128 s. ISBN 978-80-8983102-9.

13. ŠTEFANOVIČ, M. 2009. Právna úprava ochrany pôdy v Slovenskej republike. Česká společnost pro právo životního prostředí. [online], [accessed: 2016-11-21]. Available at: <www.cspzp.com/dokumenty/ konference01/stefanovic.doc>.

14. TAKÁČ, I. - LAZÍKOVÁ, J. 2013. Právna úprava nájomných zmlúv na trhu s prenajímaním pôdy na Slovensku. In Agrárne právo EÚ, vol. 2, no. 1, pp. 32-36. ISSN 1338-6891.

15. VEREŠPEJOVÁ, A. 2009. Čistá pôda - bude ešte? [online], [accessed: 2016-11-21]. Available at: <http://www.agroserver.sk/news/cistapoda-bude-este>

16. BALDOCK, J. A. - SKJEMSTAD, J. O. 1999. Soil organic carbon/soil organic matter. In Soil Analysis: an Interpretation Manual (Peverill, K.I. - Sparov, L.A. - Reuter, D.J.), pp. 159-170, CSIRO Publishing: Collingwood.

Contact address/ Kontaktná adresa

doc. JUDr. Lucia Palšová, PhD.

Department of Law, FESRD, SUA Nitra,

Tr. A. Hlinku 2, 94976 Nitra,

tel.: +421 376415079 , e-mail: lucia.palsova@uniag.sk

Ing. Bc. Ina Melišková

Department of Law, FESRD, SUA Nitra,

Tr. A. Hlinku 2, 94976 Nitra,

tel.: +421 37641 5078, e-mail: xmeliskova@is.uniag.sk

prof. JUDr. Anna Bandlerová, PhD.

Department of Law, FESRD, SUA Nitra,

Tr. A. Hlinku 2, 94976 Nitra,

tel. +421 37641 5077, e-mail: anna.bandlerova@uniag.sk 